\title{
Internalūs sunkumai ir mentalizacija paauglystëje: žvalgomasis tyrimas
}

\author{
Lina GERVINSKAITĖ-PAULAITIENE ${ }^{1}$ \\ Vilniaus universitetas
}

\begin{abstract}
Santrauka. Mokslinèje literatūroje atkreipiamas dèmesys i galimas internalių sunkumų ir mentalizacijos sąsajas, tačiau negausių pradinių tyrimų rezultatai yra prieštaringi. Ypač mažai yra žinoma apie galimas internalių sunkumų ir mentalizacijos sąsajas paauglystėje. Šio žvalgomojo tyrimo tikslas yra ịvertinti paaugliu internalių sunkumų ir mentalizacijos sąsajas. Metodika. Tyrime dalyvavo 64 paaugliai (40 merginų ir 24 vaikinai), kuriu amžius 13-17 m. Paauglių mentalizacijai vertinti taikytas Vidinių būsenų atpažinimo iš akiu testas (vaiku versija) (Baron-Cohen, Wheelwright, Spong, Scahill, \& Lawson, 2001) ir Situacinès istorijos (Gervinskaitè-Paulaitienè ir Barkauskiené, 2014), paauglių internalius sunkumus vertino tèvai - užpildè 6-18 metu vaiko elgesio aprašą (Achenbach \& Rescorla, 2001). Rezultatai. Nerimastingumo / depresiškumo, užsisklendimo / depresiškumo ir bendri internalūs sunkumai nèra susiję su mentalizacijos netikslumais paauglystėje. Didesnès paaugliu somatinės problemos yra susijusios su tikslesniu kitu žmonių elgesio paaiškinimu. Tyrimo rezultatai yra svarbūs planuojant tolesnius emocinių sunkumų ir mentalizacijos tyrimus paauglystejje.
\end{abstract}

Pagrindiniai žodžiai. Internalūs sunkumai, paaugliai, mentalizacija, emociniai sunkumai

Ivadas

Pastaraisiais metais vis daugeja tyrimų, analizuojančių mentalizacijos, t. y. savo ir kitų žmonių elgesio supratimo, susijusio su psichikos būsenomis (Allen, 2006), ir psichopatologijos sąsajas. Tyrimais aptinkama ryšių tarp ribinio asmenybės sutrikimo simptomų (Ha, Sharp, Ensink, Fonagy, \& Cirino, 2013), valgymo sutrikimų (Cate, Khademi, Judd, \& Miller, 2013), eksternalių sunkumu (Sharp, Croudace, \& Goodyer, 2007; Gervinskaitè-Paulaitienè ir Barkauskiené, 2014) ir netikslios arba tendencingos mentalizacijos. Tyrimu rezultatai prisideda prie bandymu empiriškai patikrinti Fonagy ir kitų mentalizacijos teorijos autorių (Fonagy, Bateman \& Bateman, 2011) keliamą idèją, kad vienokie ar kitokie mentalizacijos netikslumai turètų būti būdingi visiems psichologiniams sunkumams. Kol kas dar tyrimuose labai mažai dėmesio skiriama internalių sunkumų, kurie apima depresijos, užsisklendimo, nerimo, somatinių problemų simptomus (Achenbach \& Rescorla, 2001), ir mentalizacijos sąsajoms paauglystejje.

Pakankamai tiksli mentalizacija yra svarbi tarpasmeninių santykių palaikymui, reikalinga sėkmingam socialiniam funkcionavimui (Fonagy \& Allison, 2012), realistiškam kitų žmonių ir savęs tarpasmeniniame kontekste supratimui. Nors internalūs sunkumai visų pirma yra apibūdinami emociniais simptomais, tyrimai rodo, kad jie yra susiję ir su tarpasmeninio funkcionavimo problemomis (Weightman, Air, \& Baune, 2014), prastesniais socialiniais igūdžiais (Letcher, Smart, Sanson, \& Toumbourou, 2008). Vienas būdụ geriau suprasti tarpasmeninio funkcionavimo sunkumus, susijusius su internaliais sunkumais, gali būti mentalizacijos tyrimai. Remiantis atskirų socialinès informacijos apdorojimo ypatumų tyrimais, išryškèja, kad internalių sunkumų turintys vaikai pasižymi tendencingumu apdorodami su socialinėmis sąveikomis susijusią informaciją, yra linkę neigiamai interpretuoti socialinę informaciją (Luebbe, Bell, Allwood, Swenson, \& Early, 2010). Atsižvelgiant ị tai, galima kelti prielaidas, kad paaugliams, turintiems nerimo, depresijos, somatinių problemų, gali būti būdingas netikslus kitų žmonių vidinių būsenų ir jų elgesio supratimas, t. y. netiksli mentalizacija, tačiau tokių tyrimų paauglystèje trūksta.

Pradiniai negausių tyrimų vaikystėje duomenys yra prieštaringi. Ostlem, Bahar ir Jesse (2010) tyrimas, kuriame mentalizacija buvo vertinta naudojant interviu apie vaiku patyrimus tarpasmeniniuose santykiuose, atskleidè, kad geresnè vaikų mentalizacija buvo susijusi su jų mažesniais internaliais sunkumais. Tie vaikai, kurie savo pasakojimuose atsiskleide kaip galintys suteikti prasmę savo ir kitų emociniams išgyvenimams, nurodyti ir suprasti su tarpasmeniniais santykiais susijusias savo ir kitụ mintis, emocijas, turèjo mažiau internalių sunkumų. Kitame tyrime, kuriame mentalizacija buvo vertinta vaikams pateikus trumpas socialinių sąveikų istorijas ir paprašius jose ịsivaizduoti save ir atsakyti, ką kiti vaikai apie juos galvotų, nebuvo aptikta sąsajų tarp mentalizacijos tendencingumo ir emocinių problemų (Sharp, Croudace, \& Goodyer, 2007).

Siekiant kelti tolesnes prielaidas, kokie galètų būti paauglių, turinčių internalių sunkumų, mentalizacijos ypatumai, svarbu analizuoti ir tyrimus, kurie nagrinèja, kaip gebejimas suprasti psichikos būsenas ir paaiškinti žmonių elgesi yra susijęs su emociniais sunkumais suaugusių žmonių imtyse.

Lee, Harkness, Sabbagh, \& Jacobson (2005) tyrimas rodo, kad žmonès, sergantys tiek vidutine, tiek sunkia depresija, prasčiau atpažįsta vidines kitų žmonių būsenas. Kituose tyrimuose buvo atskirai tiriamas vidinių būsenų

Kontaktinis asmuo: Lina Gervinskaité-Paulaitienè, Vilniaus universitetas, Universiteto 9/1, Vilnius 01513, Lietuva. El. paštas: lina.gervinskaite@fsf.vu.lt. 
atpažinimas ir sudėtingų vidinių būsenų supratimas, kai reikia atsižvelgti ị situacinę informaciją. Juose gautos sąsajos tik tarp prastesnio sudètingų vidinių būsenų supratimo ir depresijos simptomų, bet ne tarp vidinių būsenų atpažinimo ir depresijos (Wolkenstein, Schönenberg, Schirm, \& Hautzinger, 2011; Cusi, Nazarov, MacQueen, \& McKinnon, 2013). Viename tyrimų mentalizacija yra nagrinejjama kaip gebejjimas suprasti prieraišumo santykių patirtis psichikos būsenų perspektyvoje. Taubner, Kessler, Buchheim, Kächele ir Staun (2011) savo studijoje nerado šio gebejjimo skirtumų tarp turinčių ir neturinčių klinikinès depresijos simptomų tyrimo dalyvių. Vienas iš nedaugelio populiacinės imties tyrimų atskleidžia kitokias depresijos simptomų ir vidinių būsenų atpažinimo sąsajas. Harkness, Sabbagh, Jacobson, Chowdrey, \& Chen (2005) atlikta studija rodo, kad jauni suaugusieji, turintys daugiau depresijos simptomų, geriau atpažįsta kitų žmonių vidines būsenas. Tai autoriai bando aiškinti tuo, kad neryškūs depresijos simptomai padidina žmonių jautrumą socialinei informacijai, skatina juos subtiliau analizuoti kitų žmonių elgesị (Harkness et al., 2005). Panašius rezultatus gavo ir Poletti, Sonnoli ir Bonuccelli (2014) tyrime, kuriuo nustatė ryši tarp moterų gebejjimo geriau atpažinti kitų vidines būsenas ir lengvos depresijos simptomų. Apžvelgti tyrimų rezultatai yra prieštaringi, kol kas duomenys rodo labai skirtingas sąsajas arba neatskleidžia jokių skirtumų tarp depresijos simptomų turinčių ir neturinčių žmonių mentalizacijos.

Nerimo tyrimai rodo, kad didesnis socialinis nerimas yra susijęs tiek su prastesniu vidinių būsenų (emocijų, ketinimų, norų, minčių) atpažinimu, tiek su sudėtingų būsenų supratimu (Hezel \& Nally, 2014). O'Toole, Hougaard ir Mennin (2013) atlikta emocijų atpažinimo ir supratimo ir socialinio nerimo sąsajų tyrimų metaanalizė atskleidžia panašius rezultatus -stipresnis ryšys išryškèja tarp didesnio socialinio nerimo ir prastesnio gebejjimo suprasti sudėtingas emocijas ir silpnesnis ryšys su gebėjimu atpažinti bazines emocijas. Plana, Lavoie, Battaglia, ir Achima (2014) atliktos socialinio pažinimo ir skirtingų nerimo sutrikimų sąsajų metaanalizès duomenimis, nerimo simptomai ir socialinio pažinimo sunkumai yra susiję, tačiau jie ryškiausi potrauminio streso sutrikimo atvejais, o esant kitiems nerimo sutrikimams nėra tokie stiprūs. Šie tyrimai leidžia daryti prielaidą, kad žmonès, kurie turi ryškius nerimo simptomus, gali pasižymėti prastesne ị kitus žmones nukreipta mentalizacija.

Apžvelgus tyrimus atsiskleidžia, kad kol kas aptinkama nevienodų sąsajų tarp internalių sunkumų ir mentalizacijos vaikystejje bei skirtingų internalių sunkumų simptomų suaugusiųjų imtyse. Atsižvelgiant ị tai, tampa dar svarbiau tirti šias sąsajas paauglysteje. Taigi šio žvalgomojo tyrimo tikslas yra įvertinti paauglių internalių sunkumų ir mentalizacijos sąsajas.

\section{Metodika}

\subsection{Tyrimo dalyviai}

Tyrime dalyvavo 64 paaugliai iš dviejų bendrojo lavinimo mokyklų (40 merginų, 24 vaikinai) nuo 13 iki 17 metų ( $M$ $=15,09, S D=1,29)$ ir jų tẻvai.

\subsection{Tyrime naudoti instrumentai}

Mentalizacijai vertinti taikytas Vidiniu būsenu atpažinimo iš akiu testas (vaiku versija) (sutrumpintai - Akiu testas) (The Children's version of the Reading the Mind in the Eyes Test, Baron-Cohen, Wheelwright, Spong, Scahill, \& Lawson, 2001). Testas vertina tyrimo dalyvio gebėjimą atpažinti žmogaus vidines būsenas, remiantis žmogaus akių srities nuotrauka. Teste yra 28 nuotraukos, kiekvienai jų pateikiami keturi vidines būsenas apibūdinantys žodžiai. Tyrimo dalyvio prašoma pasirinkti žodị, kuris, jo manymu, geriausiai atspindi, ką žmogus nuotraukoje jaučia, galvoja ar kokia yra jo būsena. Testo ịvertis yra teisingų atsakymų suma, svyruoja nuo 0 iki 28.

Situacinès istorijos (SI) (Gervinskaitè-Paulaitienè ir Barkauskienè, 2014) taip pat naudotos ịvertinti mentalizacijai. Šis metodas leidžia vertinti, kaip paaugliai aiškina kito žmogaus elgesị (platesni paties metodo ir jo kūrimo aprašymą žr. Gervinskaitè-Paulaitienè ir Barkauskienė, 2014). Tyrimo dalyviui pateikiamos 9 trumpos istorijos, kuriose aprašoma tarpasmeninè situacija, sukelianti neigiamas emocijas, ir joje dalyvaujančio veikejjo elgesys. Tyrimo dalyvio prašoma atsakyti ị klausimą, kaip jis mano, kodėl pagrindinis veikèjas taip pasielgè. Atsakymai vertinami pagal dvi kategorijas: emocijos identifikavimas (ar teisingai nurodoma, kokią emociją veikejjas galejjo patirti) ir elgesio intencijos identifikavimas (ar teisingai nurodoma, kokia veikejjo elgesio intencija, ketinimas, noras, tikslas). Ivertinus respondento atsakymus, apskaičiuojami trys įverčiai: emocijos identifikacija (svyruoja nuo 0 iki 9), intencijos identifikacija (svyruoja nuo 0 iki 9) ir bendras įvertis (nuo 0 iki 18). Didesnis ịvertis rodo didesni mentalizacijos tikslumą.

6-18 metu vaiko elgesio aprašas (CBCL6/18, Achenbach \& Rescorla, 2001) naudotas paauglių internaliems sunkumams vertinti. Šị klausimyną pildè vienas iš paauglių tėvų. Klausimynas leidžia ịvertinti nerimastingumo / depresiškumo, užsisklendimo / depresiškumo sunkumus ir somatinius skundus. Sudèjus šių sunkumų įverčius, gaunamas bendras internalių sunkumų lygis. 


\subsection{Tyrimo eiga}

Tyrimas vyko dviejose bendrojo lavinimo mokyklose. Gavus mokyklų direktorių sutikimą, paaugliams buvo pristatytas tyrimas, jiems išdalyti vokai tėvams su informuotu sutikimu ir prašymu užpildyti 6-18 metų vaiko elgesio aprašą (CBCL6/18, Achenbach \& Rescorla, 2001). Paaugliai, kurių tėvai sutiko, kad jų vaikai dalyvautų tyrime ir užpildè pridètą klausimyną, pildè testus mokykloje pamokų metu.

\section{Rezultatai}

Visu pirma, buvo ịvertintas paauglių internaliu sunkumų lygis remiantis lietuviškomis Žukauskienės, Kajokienės ir Vaitkevičiaus (2012) nustatytomis normomis. Šiame tyrime turinčiais sunkumu yra laikomi tie paaugliai, kurie turi tiek rizikos, tiek nuokrypio lygio sunkumų. Iš tyrimo dalyvių $6(9,4 \%)$ paaugliai turi nerimastingumo / depresiškumo sunkumų, $8(12,5 \%)$ paaugliai - užsisklendimo / depresiškumo sunkumų, 8 (12,5\%) paaugliai - somatinių problemų ir $11(17,2 \%)$ paauglių - internalių sunkumu.

Remiantis šiuo skirstymu, apskaičiuoti vidutiniai mentalizacijos įverčiai (1 lentelè) grupèse, pritaikytas Manno ir Whitney kriterijus ir pagal tai palyginti turintys ir neturintys internalių sunkumų paaugliai. Atlikus analizę paaiškèjo, kad tarp grupių neatsiskleidè statistiškai reikšmingų gebejjimo atpažinti vidines būsenas iš akių skirtumų $(U=223,5$, p > 0,05), taip pat neaptikta skirtumų tarp intencijos identifikavimo tikslumo aiškinant kito žmogaus elgesị $(U=258,0$, $\mathrm{p}>0,05)$. Nors rezultatai rodo, kad internalių sunkumų turintys paaugliai prasčiau identifikuoja kito žmogaus emociją aiškindami jo elgesị, šis skirtumas tik artèja prie statistinio reikšmingumo lygmens $(U=192,5, p<0,1)$. Palyginus paauglius, turinčius ir neturinčius nerimastingumo / depresiškumo, užsisklendimo / depresiškumo ir somatinių problemų, skirtumų tarp mentalizacijos įverčių taip pat nerasta.

1 lentelè. Elgesio priežasčių aiškinimo ir vidinių būsenų atpažinimo vidutiniai rangai internalių sunkumų turinčių ir neturinčių paauglių grupèse

\begin{tabular}{|c|c|c|c|c|c|c|c|c|}
\hline & \multicolumn{3}{|c|}{$\begin{array}{l}\text { Nerimastingumas } \\
\text { Depresiškumas }\end{array}$} & \multirow{2}{*}{$\begin{array}{c}\text { Užsisklendimas } \\
\text { Depresiškumas } \\
\text { Neturintys } \\
(\mathrm{N}=56) \\
\end{array}$} & \multicolumn{2}{|c|}{ Somatiniai skundai } & \multicolumn{2}{|c|}{ Internalūs sunkumai } \\
\hline & $\begin{array}{l}\text { Turintys } \\
(\mathrm{N}=6)\end{array}$ & $\begin{array}{l}\text { Neturintys } \\
(\mathrm{N}=58)\end{array}$ & $\begin{array}{c}\text { Turintys } \\
(\mathrm{N}=8)\end{array}$ & & $\begin{array}{l}\text { Turintys } \\
(\mathrm{N}=8)\end{array}$ & $\begin{array}{c}\text { Neturintys } \\
(\mathrm{N}=56)\end{array}$ & $\begin{array}{l}\text { Turintys } \\
(\mathrm{N}=11)\end{array}$ & $\begin{array}{c}\text { Neturintys } \\
(\mathrm{N}=53)\end{array}$ \\
\hline & \multicolumn{8}{|c|}{ Rangų vidurkiai } \\
\hline $\begin{array}{l}\text { SI emocijų } \\
\text { identifikavimas }\end{array}$ & 25,67 & 33,21 & 32,94 & 32,44 & 21,00 & 34,14 & 23,50 & 34,37 \\
\hline $\begin{array}{l}\text { SI intencijų } \\
\text { identifikavimas }\end{array}$ & 23,08 & 33,47 & 30,81 & 32,74 & 40,88 & 31,30 & 35,55 & 31,87 \\
\hline SI bendras ịvertis & 20,33 & 33,76 & 31,31 & 32,67 & 28,00 & 33,14 & 26,82 & 33,68 \\
\hline $\begin{array}{l}\text { Vidinių būsenų } \\
\text { atpažinimas }\end{array}$ & 26,42 & 33,13 & 29,19 & 32,97 & 31,25 & 32,68 & 26,32 & 33,78 \\
\hline
\end{tabular}

Siekiant ịvertinti internalių sunkumų sąsajas su mentalizacijos tikslumu visoje tyrimo imtyje, buvo apskaičiuotas Spearmano koreliacijos koeficientas (2 lentelè). Kaip matome iš 2 lentelès, statistiškai reikšmingos nestiprios teigiamos koreliacijos atsiskleidè tarp somatinių skundų ir intencijų identifikacijos aiškinant istorijos veikejo elgesio priežastis ir bendro elgesio aiškinimo ịverčio. Tie paaugliai, kuriuos tèvai įvertino kaip turinčius daugiau somatinių skundų, gebėjo tiksliau nusakyti galimas istorijos veikèjo elgesio priežastis - identifikuoti jo intenciją, slypinčią už elgesio. Koreliacija tarp bendrų internalių sunkumų ir intencijų identifikavimo tik artèja prie statistinio reikšmingumo lygmens, tačiau jo nepasiekia. Kitos sąsajos buvo silpnos ir statistiškai nereikšmingos.

2 lentelè. Internaliụ sunkumų ir elgesio priežasčių aiškinimo bei vidiniu būsenụ atpažinimo sąajojos $(\mathbf{N}=64)$

\begin{tabular}{|c|c|c|c|c|}
\hline & $\begin{array}{c}\text { Nerimastingumas } \\
\text { Depresiškumas }\end{array}$ & $\begin{array}{l}\text { Užsisklendimas } \\
\text { Depresiškumas }\end{array}$ & Somatiniai skundai & Internalūs sunkumai \\
\hline SI emocijų identifikavimas & 0,098 & $-0,179$ & 0,092 & $-0,012$ \\
\hline SI intencijų identifikavimas & 0,126 & 0,032 & $0,316^{*}$ & $\underline{0,224}$ \\
\hline SI bendras ịvertis & 0,209 & $-0,144$ & $0,304^{*}$ & 0,153 \\
\hline Vidinių būsenų atpažinimas & 0,062 & $-0,061$ & 0,074 & 0,042 \\
\hline
\end{tabular}

Pastaba. ${ }^{*} \mathrm{p}<0,05$, pabrauktos reikšmès $-\mathrm{p}<0,01$. 


\section{Rezultatų aptarimas}

Šiuo tyrimu siekta atlikti pradinę internalių sunkumų ir mentalizacijos sąsajų analizę paauglystėje. Žvalgomasis tyrimas atskleide, kad nerimastingumas / depresiškumas, užsisklendimas / depresiškumas ir bendri internalūs sunkumai nėra susiję su netikslia mentalizacija. Tik somatiniai skundai siejasi su mentalizacija, tačiau ryšys yra teigiamas, t. y. daugiau somatinių problemų turintys paaugliai pasižymi tikslesne mentalizacija.

Visų pirma, lyginome paaugliụ, turinčių riziką keliančių internalių sunkumų, ir paauglių, kurių internalūs sunkumai patenka į normos ribas, mentalizaciją. Rezultatai atskleidè, kad abiejų grupių paaugliai vienodai tiksliai geba atpažinti kitų žmonių vidines būsenas ir paaiškinti elgesị, identifikuodami jų patiriamą emociją ir intenciją, slypinčią už matomo elgesio. Mūsų tyrimo rezultatai dera su dalimi Wolkenstein ir kolegų (2011) ir Cusi ir kolegų (2013) tyrimų duomenų, kurie rodo, kad žmonès, kuriems diagnozuota depresija, nesiskiria nuo depresija nesergančių žmonių pagal vidinių būsenų atpažinimo tikslumą. Nors šiuose tyrimuose buvo nustatytas prastesnis depresija sergančių žmonių gebejjimas suprasti sudètingas vidines būsenas remiantis situacine informacija, mūsų tyrimas šių skirtumų neatskleidè. Svarbu atkreipti dèmesị, kad mūsų tyrimo dalyviai nebuvo iš klinikinès imties, ir tai gali būti viena šių skirtumų priežasčių.

Analizuodami nerimastingumo / depresiškumo, užsisklendimo / depresiškumo ir bendrų internalių sunkumų sąsajas, visoje imtyje neradome ryšiu tarp didesnių internalių problemų ir mentalizacijos netikslumo. Šie rezultatai papildo Sharp, Croudace ir Goodyer (2007) tyrimo duomenis, rodančius, kad vaikysteje emociniai sunkumai ir mentalizacijos netikslumas nèra susiję. Mūsų tyrimo rezultatai nedera su Hezel ir Nally (2014), O'Toole, Hougaard ir Mennin (2013), Plana ir kolegų (2014) atliktais tyrimais, rodančiais, kad skirtingi nerimo simptomai gali sietis su prastesniu gebejjimu atpažinti vidines būsenas ir suprasti bei paaiškinti sudètingas vidines būsenas. Vis dèlto šiuose tyrimuose buvo tiriami klinikinio lygmens nerimo simptomai, išskiriant atskirus nerimo sutrikimus. Gali būti, kad populiacijos imtyje, kur nerimo sunkumai vertinami remiantis dimensiniu požiūriu, neidentifikuojant atskirų nerimo sutrikimų simptomų, sąsajos nèra tokios ryškios.

Netiketos sąsajos buvo rastos tarp somatinių problemų ir mentalizacijos. Paaugliai, kurie tèvų buvo ịvertinti kaip turintys daugiau somatinių nusiskundimų, tiksliau paaiškino kitų žmonių elgesio priežastis pateiktose situacijose ir tiksliau nurodè už elgesio slypinčią intenciją. Apie šią sąsają galima kalbèti keliais aspektais. Visų pirma, svarbu atkreipti dèmesị $i$ tai, kad paauglių sunkumus vertino vienas iš jų tẻvų. Internalūs sunkumai, kurie yra sunkiau pastebimi aplinkiniams, gali būti lengviau matomi ir suprantami kaip somatiniai skundai. Galima kelti prielaidą, kad galbūt didesni somatiniai skundai gali slëpti ryškesnius depresijos simptomus. Tokiu atveju šiuos rezultatus galètume susieti su Harkness ir kolegų (2005) tyrimo rezultatais ir jų keliamomis prielaidomis, kad galbūt nedideli depresijos simptomai padidina dèmesingumą socialinei informacijai. Svarbu pažymèti, kad dèl šių reiškinių sąsajų tyrimų trūkumo sunku pagrịstai paaiškinti galimus ryšius, todèl čia svarstomos prielaidos turètų būti vertinamos kaip preliminarios. Tolesniuose tyrimuose būtų svarbu skirti dẻmesio gilesnei teorinei galimų sąsajų tarp somatinių simptomų ir mentalizacijos analizei.

Šio žvalgomojo tyrimo rezultatai skatina tęsti teorinius ir empirinius paauglių internalių sunkumų ir mentalizacijos sąsajų tyrimus. Nors tyrimo duomenys kol kas neleidžia daryti tvirtų išvadų, jie turètų būti vertinami kaip vienas iš atspirties taškų tolesnèms analizėms.

Vienas iš galimų tyrimo ribotumų, galëjusių paveikti rezultatus, yra nedidelè populiacinè imtis. Nors dalies paauglių internalūs sunkumai vertinti kaip keliantys riziką funkcionavimui, ši grupé buvo maža. Be to, tyrime dalyvavo daugiau merginų nei vaikinų, ir šis netolygumas galëjo paveikti rezultatus. Gali būti, kad, ịtraukus ị tyrimą paauglius, kurie kreipiasi pagalbos dèl internaliu sunkumų, tyrimo rezultatai būtų kitokie. Dẻl to tolesniuose tyrimuose svarbu užtikrinti klinikinès grupės paauglių dalyvavimą, surinkti didesnę populiacinę imtị ir užtikrinti tolygų tyrimo dalyvių pasiskirstymą pagal lytị.

Šiame tyrime internalūs sunkumai buvo vertinami vieno iš tèvų, o ne pačių paauglių. Paauglių internalios problemos gali būti sunkiau pastebimos tèvams, jụ lygis gali būti netiksliai ịvertinamas, ir tai galèjo paveikti tyrimo rezultatus. İ kitus tyrimus būtų labai svarbu ịtraukti ir pačių paauglių internalių sunkumų vertinimą.

Svarstant apie kitas galimas priežastis, dèl ko nebuvo aptikta reikšmingų sąsajų tarp internalių sunkumų ir mentalizacijos, reikia atkreipti dèmesị i mentalizacijos kompleksiškumą. Visų pirma, ji gali būti apibūdinama keletu skirtingų dimensijų (platesnę apžvalgą žr. Choi-Kain \& Guderson, 2008), pavyzdžiui, nukreipta ị kitą žmogų ar ị save. Šiame tyrime buvo vertinta tik ị kitus žmones nukreipta mentalizacija. Internaliems sunkumams būdingos problemos vis dèlto visų pirma yra susijusios su intrapersonaliniu funkcionavimu, nukreiptos ị save. Gali būti, kad būtent ne ị kitą, o i save nukreiptos mentalizacijos, kai bandoma suprasti savo vidini pasauli ir elgesí, netikslumai gali ryškiau atsiskleisti šių sunkumų atvejais. Be to, mentalizacija gali būti veikiama sužadinimo ir konteksto veiksnių. Gali būti, kad ne visi mentalizacijos vertinimo metodai yra pakankamai jautrūs, kad galètų užfiksuoti mentalizacijos netikslumus emocinių sunkumų atvejais. Planuojant tolesnius tyrimus, būtų svarbu ieškoti būdų identifikuoti mentalizacijos dimensijas ir konteksto veiksnius, kurie gali būti glaudžiausiai susiję su mentalizacijos netikslumais internalių sunkumų atvejais, ir ieškoti tyrimo strategijų bei metodų, leidžiančių tai ịvertinti tyrimuose. 


\title{
Išvados
}

- Nerimastingumo / depresiškumo, užsisklendimo / depresiškumo ir bendri internalūs sunkumai paauglystėje nėra susiję su vidinių būsenų iš akių srities atpažinimo tikslumu ir kitų žmonių elgesio priežasčių paaiškinimo, identifikuojant jų patiriamą emociją ir elgesio intenciją, tikslumu.

- Didesnès paauglių somatinès problemos yra susijusios su tikslesniu kitų žmonių elgesio priežasčių paaiškinimu ir tikslesniu intencijos identifikavimu aiškinant kitų elgesio priežastis.

\section{Padèka}

Nuoširdžiai dėkoju doc. dr. Rasai Barkauskienei už vertingas pastabas ir pagalbą atliekant tyrimą bei rekomendacijas rengiant publikaciją.

\section{Internalizing difficulties and mentalization in adolescence: exploratory study}

\author{
Lina GERVINSKAITĖ-PAULAITIENE் ${ }^{1}$ \\ Vilnius University \\ ${ }^{I}$ Corresponding author: lina.gervinskaite@fsf.vu.lt
}

\begin{abstract}
Recently, possible relationships between internalizing difficulties and mentalization have been receiving increasing attention in scientific literature. However, first empirical results are inconsistent and there is a lack of studies investigating the relationships between internalizing symptoms and mentalization in adolescence.

This exploratory study aims to analyse the relationships between adolescents' internalizing difficulties and their mentalizing. Participants. Sixty four adolescents (40 girls and 24 boys) aged $13-17$ participated in the study. Methods. Mentalization was assessed using Reading the Mind from the Eyes Test (child version) (Baron-Cohen et al., 2001) and Situational Stories method (Gervinskaite-Paulaitienè ir Barkauskiené, 2014), internalizing difficulties were rated by adolescents' parents using Child Behaviour Checklist 6/18 (Achenbach \& Rescorla, 2001). Results. Anxious/Depressed, Withdrawn/Depressed and Overall internalizing difficulties were not related to mentalization accuracy in adolescence. Higher somatic problems were related with more correct explanation of other people's behaviour. The study results are important in planning further research of mentalizing and emotional difficulties.

Keywords. Internalizing symptoms, mentalizing, adolescents, emotional difficulties
\end{abstract}




\section{Literatūra}

Achenbach, T. M., \& Rescorla, L. A. (2001). Manual for the ASEBA School-Age Forms \& Profiles. Burlington, VT: University of Vermont, Research Center for Children, Youth, \& Families.

Baron-Cohen, S., Wheelwright, S., Spong, A., Scahill, V., \& Lawson, J. (2001). Are intuitive physics and intuitive psychology independent? A test with children with Asperger Syndrome. Journal of Developmental and Learning Disorders, 5, 47-78.

Cate, R., Khademi, M., Judd, P., \& Miller, H. (2013). Deficits in mentalization: A risk factor for future development of eating disorders among preadolescent girls. Advances in Eating Disorders, 1 (3).

Choi-Kain, L. W., Gunderson, J. G. (2008). Mentalization: Ontogeny, assessment, and application in the treatment of borderlinepersonality disorder. Am J. Psychiatry, 165 (9), 1127-1135. doi: 10.1176/appi.ajp.2008.07081360.

Cusi, A. M., Nazarov, A., MacQueen, G. M., \& McKinnon, M. C. (2013). Theory of mind deficits in patients with mild symptoms of major depressive disorder. Psychiatry Research, 210 (2), 672-674. doi: 10.1016/j.psychres.2013.06.018.

Fonagy, P., Bateman, A., Bateman, A. (2011). The widening scope of mentalizing: A discussion. Psychology and Psychotherapy: Theory, Research and Practice, 84, 98-110.

Fonagy. P., \& Allison, E. (2012). What is Mentalization? The Concept and Its Foundations in Developmental Research. In N. Midgley, I. Vrouva (Eds.), Mentalization-based Interventions with Children, Young People and Their Families (pp. 9-11). East Sussex: Routledge.

Gervinskaitė-Paulaitienè, L., ir Barkauskienè, R. (2014). Elgesio sunkumų turinčiu paaugliu mentalizacijos ypatumai. International Journal of Psychology: A Biopsychosocial Approach, 15, 47-68. doi: 10.7220/2345-024X.15.3.

Ha, C., Sharp, C., Ensink, K., Fonagy, P., \& Cirino, P. (2013). The measurement of reflective function in adolescents with and without borderline traits. Journal of Adolescence, 36 (6), 1215-1223. doi: 10.1016/j.adolescence.2013.09.008.

Harkness, K., Sabbagh, M., Jacobson, J., Chowdrey, N., \& Chen, T. (2005). Enhanced accuracy of mental state decoding in dysphoric college students. Cognition \& Emotion, 19 (7), 999-1025. doi: 10.1080/02699930541000110.

Hezel, D. M., \& McNally, R. J. (2014). Theory of mind impairments in social anxiety disorder. Behavior Therapy, 45 (4), $530-540$.

Lee, L., Harkness, K. L., Sabbagh, M. A., \& Jacobson, J. A. (2005). Mental state decoding abilities in clinical depression. Journal of Affective Disorders, 86 (2-3), 247-258. doi: 10.1016/j.jad.2005.02.007.

Luebbe, A. M., Bell, D. J., Allwood, M. A., Swenson, L. P., \& Early, M. C. (2010). Social Information Processing in Children: Specific Relations to Anxiety, Depression, and Affect. Journal of Clinical Child \& Adolescent Psychology, 39 386-399. doi: 10.1080/15374411003691685.

O’Toole, M. S., Hougaard, E., \& Mennin, D. S. (2013). Social anxiety and emotion knowledge: A meta-analysis. Journal of Anxiety Disorders, 27 (1), 98-108. doi: 10.1016/j.janxdis.2012.09.005.

Ostler, T., Bahar, O. S., \& Jessee, A. (2010). Mentalization in children exposed to parental methamphetamine abuse: Relations to children's mental health and behavioral outcomes. Attachment \& 12 (3), 193-207. doi: 10.1080/14616731003759666.

Plana, I., Lavoie, M. A., Battaglia, M., \& Achim, A. M. (2014). A meta-analysis and scoping review of social cognition performance in social phobia, posttraumatic stress disorder and other anxiety disorders. Journal of Anxiety Disorders, 28 (2), 169-177. doi: 10.1016/j.janxdis.2013.09.005

Poletti, M., Sonnoli, A., \& Bonuccelli, U. (2014). Mild depressive symptoms are associated with Enhanced Affective Theory of Mind in nonclinical adult women. The Journal of Neuropsychiatry and Clinical Neurosciences, 26 (2), E63-E64. doi: 10.1176/appi.neuropsych.13060123.

Taubner, S., Kessler, H., Buchheim, A., Kächele, H., \& Staun, L. (2011). The role of mentalization in the psychoanalytic treatment of chronic depression. Psychiatry, 74 (1), 49-57.

Weightman, M. J., Air, T. M., \& Baune, B. T. (2014). A review of the role of social cognition in major depressive disorder. Frontiers in Psychiatry, 5. doi: 10.3389/fpsyt.2014.00179.

Wolkenstein, L., Schönenberg, M., Schirm, E., \& Hautzinger, M. (2011). I can see what you feel, but I can't deal with it: Impaired theory of mind in depression. Journal of Affective Disorders, 132 (1-2), 104-111. doi: 10.1016/j.jad.2011.02.010. 